\title{
Self-Regulated E-Learning and Social Attitudes for Achieving Creative Thinking of Students in Learning Physics in High School
}

\author{
Wayan Santyasa $^{1 *}$, Gede Saindra Santyadiputra ${ }^{2}$ and Made Juniantari ${ }^{3}$ \\ ${ }^{I}$ Physics Education Department, Universities education Ganesha, Indonsia, \\ ${ }^{2}$ Informatics Education Department, Universities education Ganesha, Indonsia, \\ ${ }^{3}$ Mathematics Education Department, Universities education Ganesha, Indonsia, \\ *Corresponding author. Email: santyasa@undiksha.ac.id
}

\begin{abstract}
This study aims at analyzing the differences effect of self-regulated e-learning (SReL) and direct e-learning (DeL) on creative thinking (CT) viewed from students' social attitudes (SA). Students' SA are divided into high SA (HSA) and low SA (LSA). The population was 5 classes (168 people) of class X MIPA SMAN 1 Kubutambahan Buleleng Bali at the 2019/2020 academic year. The sample was 4 classes (128 students, or $76.2 \%$ of the population) which were selected using a random assignment technique. Furthermore, 2 classes were determined as the SReL group and 2 classes as the DeL group. Data of CT and SA were collected by an essay test and a questionnaire respectively. Data were analyzed by two-way Anacova and test of hypothesis used a significance level of 5\%. The research results showed 1) There is a difference effect between SReL and DeL on CT. The CT of students learning using the SReL model was significantly higher than those studying with the DeL model. 2) There is a difference effect between HSA and LSA on CT. Students who have HSA achieve higher CT than those who have LSA. There is no interactive effect between learning models and students' SA towards CT.
\end{abstract}

Keywords: Self-regulated e-learning, direct e-learning, social attitude, creative thinking

\section{INTRODUCTION}

The 21 st century is a challenge for everyone in the world related to having competence. The National Education Association identifies four important competencies in the 21st century, namely (1) critical thinking and problem solving, (2) communication, (3) collaboration, and (4) creativity and innovation. This challenge has implications for learning in schools, including learning physics in high school. The students' creative thinking in physics learning is a challenge in itself. The ability to think creatively includes the skills to generate new ideas, evaluate, describe, and select ideas [1]. In fact, the 2013 Curriculum provides opportunities for teachers to develop students' creative thinking skills. However, the reality is that students' creative thinking in learning physics in high school is very less [2],[3]. On a scale of 100 the average score of students' creative thinking skills is 28.53 in the very poor category [4]. The low of students' creative thinking ability is because teachers are less oriented towards developing creative thinking during learning and teachers still tolerate the direct learning model [2]-[6]. One learning model that accommodates the development of students' creative thinking in physics learning is the self-regulated learning (SRL) model. The model affects students' creative thinking abilities [7]. The SRL model is a process that involves all forms of thoughts, feelings, or actions that are deliberately carried out and controlled by students to maximize their knowledge and skills to complete the given task and adjust to certain conditions [8]. This SRL conception indicates that the model has a synergy with emotions including students 'social attitudes 
to empower students' thinking skills including their creative thinking skills in learning. Two types of advantages of the SRL model in learning are (a) SRL can be used to learn independently throughout life, (b) SRL has a combination of academic learning abilities with selfcontrol so that learning can be easier [9]. Wool folk also stated that the SRL model is a process used by students to activate and maintain their thoughts, actions, and emotions in order to achieve learning goals.

In line with the rapid development of information technology, the direct learning model and the selfregulated learning model can be used as pedagogical content in the e-learning system. The terms for the two learning models are direct e-learning (DeL) and selfregulated learning (SReL). The integration of the two learning models into e-learning is intended so that both can provide learning performance in accordance with the paradigm of "independent learning independent campus" in the current era. The results of the study show that elearning can improve students' creative thinking skills [10]-[12]. This is because content-based e-learning only tolerates the direct learning model, so that it has less than optimal effect on creative thinking.

The social network-based e-learning model synergizes the potential of e-learning with the social attitudes of students, thus supporting the development of students' creative thinking in learning. Based on this background, this study aims to analyze the differences effect of SReL and DeL in achieving creative thinking in terms of students' social attitudes. Students' social attitudes are divided into high social attitudes (HSA) and low social attitudes (LSA).

\section{METHODOLOGY}

This quasi-experimental research used a post-test only control group design. The population was 5 classes (168 people) of class X MIPA SMAN 1 Kubutambahan Buleleng Bali at the 2019/2020 academic year. The five population classes are academically homogeneous, because their formation is based on random individual students. The methodology of the population condition allows the sample selection to be carried out randomly by class. The sample was 4 classes (128 students, or $76.2 \%$ of the population) which were selected using a random assignment technique. Furthermore, 2 classes were assigned as the SReL group and 2 classes as the DeL group.

This study examines the learning model as an independent variable which consists of two categories, namely SelfRegulated e-Learning (SReL) and Direct e-Learning (DeL). The dependent variable studied is creative thinking ability.

The stages of the SReL learning process are as follows. 1) Analyzing the learning task, students collect all relevant information to form an overview of a given learning task, learning resources, and an estimate of how to do it or do it.
2) Setting goals and devising plans. In this process, students understand a complete picture of the learning task to be performed which can help self-regulated learning actors set goals. Then, plans are developed to achieve these goals. 3) Enacting tactics and strategies to accomplish the task. In this stage students apply the tactics and strategies that have been determined to complete the task. Students pay particular attention during this stage as they monitor how well planning is being carried out. 4) Regulating learning. At this stage, students evaluate and make decisions whether there is a change needed in the three stages above or not [9].

The stages of the DeL learning process are as follows. 1) The teacher motivates students regarding the subject matter discussed, 2) The teacher presents the subject matter followed, 3) The teacher instructs students to form groups of 3-5 people and share group assignments, 4) Students work on assignments given by the teacher in each group and formulate the report on the results of the discussion, 5) The teacher appoints the group in turn to report the results of the discussion, 6) The teacher assesses student discussion reports and gives quizzes [13].

Conceptually, creative thinking has 4 dimensions, namely 1) smooth thinking, 2) flexible thinking, 3) original thinking, and 4) elaborate thinking [14],[15]. Based on these 4 dimensions, 15 points of essay tests were determined on the study of effort, energy, momentum, and impulse. The score ranges for each item are 0-4. The test results showed that the internal consistency of the creative thinking test items moved from $r=0.388$ to $r=0.772$ and the reliability was Cronbach's alpha $=0.897$ with very high qualification categories.

The social attitude consisted of 4 dimensions, namely 1) the attitude of organizing groups, 2) the attitude of negotiating solutions, 3) the attitude of maintaining personal relationships, and 4) attitude in carrying out social analysis [16]-[18]. The 4 dimensions of social attitudes are translated into 30 items of social attitude instruments. Each item uses a Liker Scale by removing neutral elements so that the scale is degraded 1-5. The results of the trial on 291 subjects showed that the correlation coefficient of the total item of social attitude questionnaire moves from $r=0.36$ to $r=0.60$ with 30 item reliability is Alfa Cronbach $=0.91$ with very high qualifications.

The study was conducted for 4 weeks between April to May 2020 with a duration of 135 minutes per week. Before doing the treatment, students in all groups were given social attitudes to answer for a duration of 15 minutes. After doing 4 treatments, students in the SReL and DEL groups gave creative thinking posttests for 90 minutes.

The research data were analyzed using two-way analysis of covariance. As the assumption of analysis of covariance is normally distributed data, the variance of the dependent variable between groups is homogeneous, and the variance of error testing between groups is tested. The data distribution normality test used the Kolmogorov-Smirnov 
and Shapiro-Wilk statistics, the variance homogeneity test used the Levene's statistics, and the variance test for variance errors with Levene's statistics. Hypothesis testing uses a significance level of $5 \%$.

\section{RESULTS AND DISCUSSION}

The results of the descriptive analysis are presented in Table 1. These results indicate that the highest average value of students' creative thinking is achieved by students in SReLHSA cells with $\mathrm{M} 11=75.9 ; \mathrm{SD}=7.28$ with high qualification. While in other cells the SReL-LSA is M21 = 68.0; SD = 6.08; DeL-HSA M12 = 66.4; SD = 5.79, and DeL-LSA M22 $=67.8 ; \mathrm{SD}=6.50$ each with moderate qualifications.

Table 1 Results of descriptive analysis of students' creative thinking abilities

\begin{tabular}{lccc}
\hline & SReL & DeL & \\
\hline \multirow{4}{*}{ HAS } & $\mathrm{M}_{11}=75.9$ & $\mathrm{M}_{12}=66.4$ & $\mathrm{M}_{1 \mathrm{t}}=71.2$ \\
& $\mathrm{SD}=7.28$ & $\mathrm{SD}=5.79$ & $\mathrm{SD}=8.06$ \\
LSA & $\mathrm{M}_{21}=68.0$ & $\mathrm{M}_{22}=67.8$ & $\mathrm{M}_{2 \mathrm{t}}=67.9$ \\
& $\mathrm{SD}=6.07$ & $\mathrm{SD}=6.50$ & $\mathrm{SD}=8.09$ \\
& $\mathrm{M}_{\mathrm{t} 1}=71.95$ & $\mathrm{M}_{\mathrm{t} 2}=67.09$ & \\
& $\mathrm{SD}=6.71$ & $\mathrm{SD}=6.12$ & \\
\hline
\end{tabular}

Next will be presented the results of the two-way covariance analysis. However, previously presented the results of the assumption test. The results of the first assumption test are the normality test of data distribution according to the grouping of social attitudes, as in Table 2 and grouping models in Table 3. Table 2 and Table 3 show that the Kolmogorov-Smirnov and Shapiro-Wilk statistical figures are which is greater than 0.05 , so that the students' creative thinking data on HAS, LSA, SReL, and DeL are normally distributed.

The next assumption test is the homogeneity test of creative thinking variants between the two treatment groups according to social attitudes in Table 4 and according to the learning model in Table 5. Based on the two tables, it appears that Levene's statistical numbers each have a significance value greater than 0.05 ., so that the variance between groups is homogeneous.

The result of the error variance similarity test also shows that the Levene's statistical number $\mathrm{F}=0.558$ with sig $=$ 0.644 which is greater than 0.05 (Table 6). These results indicate that the variant of creative thinking is truly homogeneous.

Because the results of the assumption test have been met, the next two-way covariance analysis results are presented, as presented in Table 7.

Based on Table 7, the research findings can be presented as follows. Firstly, there is a difference in the effect between SReL and DeL on creative thinking $(\mathrm{F}=$ $35,204 ; \mathrm{p}<0.05)$. The creative thinking of students learning with the SReL model $(\mathrm{Mt1}=71.95 ; \mathrm{SD}=6.71)$ was significantly higher than those studying with the DeL model $(\mathrm{Mt} 2=67.09 ; \mathrm{SD}=6.12)$. This is in accordance with previous research [10],[12],[19]. Students who study with SReL have relatively high selfefficacy, thus supporting the development of creative thinking.

Table 2 Test of Normality of Data Distribution Based on Social Attitude Grouping

\begin{tabular}{llcccccc}
\hline Dependent & & \multicolumn{2}{c}{ Kolmogorov-Smirnova } & \multicolumn{3}{c}{ Shapiro-Wilk } \\
\cline { 2 - 7 } & Moderator & Statistic & Df & Sig. & Statistic & df & Sig. \\
\hline Variable & HAS & .152 & 42 & .066 & .932 & 42 & .095 \\
Thinking & LSA & .113 & 42 & $.200 *$ & .958 & 42 & .126 \\
\hline
\end{tabular}

Table 3 Test of Normality of Data Distribution Based on Learning Model Grouping

\begin{tabular}{llllllllr}
\hline \multirow{2}{*}{$\begin{array}{l}\text { Dependent } \\
\text { Variable }\end{array}$} & & \multicolumn{3}{c}{ Kolmogorov-Smirnova } & \multicolumn{3}{c}{ Shapiro-Wilk } \\
\cline { 3 - 9 } & Learning Models & \multicolumn{2}{c}{ Statistic } & Df & Sig. & Statistic & df & Sig. \\
\hline Creative & SReL & .149 & 42 & .089 & .949 & 42 & .061 \\
Thinking & DeL & .158 & 42 & .090 & .931 & 42 & .074 \\
\hline
\end{tabular}


Table 4 Test of Homogeneity of Variance Based on Social Attitude Grouping

\begin{tabular}{llllll}
\hline Dependent Variable & \multicolumn{1}{c}{ Levene's Statistic } & & df1 & df2 & Sig. \\
\hline \multirow{4}{*}{ Creative thinking } & Based on Mean & .021 & 1 & 82 & .885 \\
& Based on Median & .116 & 1 & 82 & .734 \\
& Based on Median and with adjusted df & .116 & 1 & 80.817 & .734 \\
& Based on trimmed mean & .036 & 1 & 82 & .851 \\
\hline
\end{tabular}

Table 5 Test of Homogeneity of Variance Based on Learning Model Grouping

\begin{tabular}{llllll}
\hline Dependent Variable & \multicolumn{2}{c}{ Levene's Statistic } & df1 & df2 & Sig. \\
\hline \multirow{5}{*}{ Creative thinking } & Based on Mean & 1.167 & 1 & 82 & .283 \\
\cline { 2 - 6 } & Based on Median & 1.224 & 1 & 82 & .272 \\
\cline { 2 - 6 } & $\begin{array}{l}\text { Based on Median and } \\
\text { with adjusted df }\end{array}$ & 1.224 & 1 & 77.726 & .272 \\
\cline { 2 - 6 } & Based on trimmed mean & 1.230 & 1 & 82 & .271 \\
\hline
\end{tabular}

Table 6 Levene's Test of Equality of Error Variances

\begin{tabular}{llll}
\hline $\mathrm{F}$ & $\mathrm{df} 1$ & $\mathrm{df} 2$ & Sig. \\
\hline .558 & 3 & 80 & .644 \\
\hline
\end{tabular}

Table 7 Test of between subject effect

\begin{tabular}{|c|c|c|c|c|c|c|}
\hline Source & & Type III Sum of Squares & $\mathrm{df}$ & Mean Square & $\mathrm{F}$ & Sig. \\
\hline \multirow[t]{2}{*}{ Intercept } & Hypothesis & 435600.012 & 1 & 435600.012 & 6866.279 & .008 \\
\hline & Error & 63.440 & 1 & $63.440^{\mathrm{a}}$ & & \\
\hline \multirow[t]{2}{*}{ MODEL } & Hypothesis & 121.10176 & 1 & 121.10176 & 35.204 & .006 \\
\hline & Error & 3.440 & 1 & $3.440^{\mathrm{b}}$ & & \\
\hline \multirow[t]{2}{*}{ SOCIAL } & Hypothesis & 63.440 & 1 & 63.440 & 18.439 & .038 \\
\hline & Error & 3.440 & 1 & $3.440^{\mathrm{b}}$ & & \\
\hline MODEL * & Hypothesis & 3.440 & 1 & 3.440 & .083 & .774 \\
\hline SOCIAL & Error & 3315.524 & 80 & $41.444^{\mathrm{c}}$ & & \\
\hline
\end{tabular}

Secondly, there is a difference in the effect between HSA and LSA on creative thinking $(\mathrm{F}=18,439$; $\mathrm{p}<$ 0.05). Students who have HSA achieve higher creative thinking $(\mathrm{M} 1 \mathrm{t}=71.2 ; \mathrm{SD}=8.06)$ than those who have LSA (M2t $=67.9 ; \mathrm{SD}=8.09$ ). This is in accordance with the results of previous research [11]. E-learning with the social network model serves as a vehicle for developing social attitudes. Good social attitudes are a source of conducive social interaction in learning that leads to the development of students' creative thinking [11].

Thirdly, there is no interactive influence between learning models and students' social attitudes towards creative thinking. Learning physics with the SReL model is accommodating to both levels of students' social attitudes in achieving creative thinking in physics learning for class X MIPA in high school. This result is a challenge for the next research to be able to prove whether or not there is an in interactive effect between the learning model and students 'social attitudes on students' creative thinking ability in learning physics in class X SMA.

\section{CONCLUSIONS}

Learning physics class X SMA on the subject matter of work, energy, impulse, and momentum using the SReL model is superior than DeL in achieving creative thinking skills. This fact is inseparable from the better innovation value in the self-regulated learning (SRL) model compared to the direct instruction (DI) model as 
e-learning content. E-learning performance is highly dependent on its content in achieving learning products. Innovative e-learning content will result in better performance compared to less innovative content. The implication is that learning with the help of technology really needs content that is in accordance with the learning needs of students, so that learning products will be produced as expected.

In achieving the ability to think creatively in physics learning for class X SMA on the subject matter of work, energy, impulse, and momentum, it is supported by high social attitudes compared to low social attitudes. This is inseparable from the SRL model which is very synergized with positive emotions in the form of good social attitudes. The implication is that in learning physics positive motivations are needed to generate positive emotions in students, including their social attitudes in interacting in learning.

The learning model (SReL versus DeL) did not significantly interact with social attitudes (high social attitude / HAS versus low social attitude / LSA) in achieving students' creative thinking abilities in physics learning. Both learning models are accommodative to both levels of social attitudes. The implication is that physics learning should continuously apply SReL by considering the social aspects of students so that their development is maintained towards a positive level.

\section{ACKNOWLEDGMENT}

Thank you to the head of SMAN 1 Kubutambahan for the permission and support given to us to conduct research in the school he leads. Thank you also to the Physics Teacher of class X of SMAN 1 Kubutambahan and Students of Physics Education Department of Universitas Pendidikan Ganesha who were involved in this research.

\section{REFERENCES}

[1] S. D. Daly, E. A. Mosyjowski, C. M. Seifert. Teaching creativity in engineering courses. Journal of Engineering Education, 103 (3) (2014) 417-449. DOI: https://doi.org/10.1002/jee.20048

[2] S. A. Damayanti, I. W. Santyasa, A. R. Sudiatmika. Pengaruh Model Problem Based-Learning Dengan Flipped Classroom Terhadap Kemampuan Berpikir Kreatif. Jurnal Kependidikan: Penelitian Inovasi Pembelajaran, 4 (1) (2020) 83-98. DOI: https://doi.org /10.21831/jk.v4i1.25460

[3] A. R. Sirait. Analysis Difficulty of Mathematical Creative Thinking Ability Reviewed From Learning Styles Through Problem Based Learning. Advances in
Social Sciences Research Journal, 5 (10) (2018) 134136. DOI: https://doi.org/10.14738/assrj.510.5378

[4] S. Lynch, J. Kuipers, C. Pyke, M. Szesze. Examining the effects of a highly rated science curriculum unit on diverse students: Results from a planning grant. Journal of Research in Science Teaching: The Official Journal of the National Association for Research in Science Teaching, 42 (8), 912-946. DOI: https://doi.org/10.1002/tea.20080

[5] S. N. Jamal, N. H. Ibrahim, N. D. A. Halim, J. Surif, S. Osman. P roblem based Learning on Creativity Domain in Problem Solving for Secondary School: A Systematic Literature Review Analysis. European Journal of Molecular \& Clinical Medicine, 7 (6) (2020) 530-541.

[6] O. Akınoğlu, R. Ö. Tandoğan. The effects of problem-based active learning in science education on students' academic achievement, attitude and concept learning. Eurasia journal of mathematics, science and technology education, 3 (1) (2007) 71-81. DOI: https:// doi.org/10.12973/ejmste/75375

[7] K. H. Kim. Can we trust creativity tests? A review of the Torrance Tests of Creative Thinking (TTCT). Creativity research journal, 18 (1) (2006) 3-14. DOI: https://doi.org/10.1207/s15326934crj1801_2

[8] J. A. Greene, R. Azevedo. A macro-level analysis of SRL processes and their relations to the acquisition of a sophisticated mental model of a complex system. Contemporary Educational Psychology, 34 (1) (2009) 18-29. DOI: https://doi.org/10.1016/j.cedpsych. 2008.05.006

[9] M. Z. Mokhtar, R. A. Tarmizi, A. F. M. Ayub, M. D. H. Nawawi. Motivation and performance in learning calculus through problem-based learning. International Journal of Asian Social Science, 3 (9) (2013) 1999 2005 .

[10] D. Prasetyowati. Development of learning videos for junior high school math subject to enhance mathematical reasoning. International Journal of Education and Practice, 8 (1) (2020) 18-25. DOI: 10.18488/journal.61.2020.81.18.25

[11] K. M. Law, V. C. Lee, Y. T. Yu. Learning motivation in e-learning facilitated computer programming courses. Computers \& Education, 55 (1) (2010) 218-228. DOI: https://doi.org/10.1016/j.compe du.2010.01.007

[12] S. Suwarno, W. Wahidin, S. H. Nur. Project-based learning model assisted by worksheet: It's effect on students' creativity and learning outcomes. JPBI (Jurnal 
Pendidikan Biologi Indonesia), 6 (1) (2020) 113-122. DOI: https://doi.org/10.22219/jpbi.v6i1.10619

[13] F. Alonso, G. López, D. Manrique, J. M. Viñes. An instructional model for web-based e-learning education with a blended learning process approach. British Journal of educational technology, 36 (2) (2005) 217-235. DOI: https://doi.org/10.1111/j.146 7-8535.2005.00454.x

[14] J. S. Renzulli, D. Siegle, S. M. Reis, M. K. Gavin, R. E. S. Reed. An investigation of the reliability and factor structure of four new scales for rating the behavioral characteristics of superior students. Journal of Advanced Academics, 21 (1) (2009) 84-108. DOI: https://doi.org/10.1177/1932202X0902100105

[15] C. Mouchiroud, T. Lubart. Children's original thinking: An empirical examination of alternative measures derived from divergent thinking tasks. The Journal of genetic psychology, 162 (4) (2001) 382-401. DOI: https://doi.org/10.1080/00221320109597491

[16] F. Azevedo, J. T. Jost, T. Rothmund, J. Sterling. Neoliberal ideology and the justification of inequality in capitalist societies: Why social and economic dimensions of ideology are intertwined. Journal of Social Issues, 75 (1) (2019) 49-88. DOI: https://doi.org /10.1111/josi.12310

[17] D. Goleman. Emotional intelligence. Jakarta: PT Gramedia Pustaka Utama.2000.

[18] K. S. Kendler, X. Q. Liu, C. O. Gardner, M. E. McCullough, D. Larson, C. A. Prescott. Dimensions of religiosity and their relationship to lifetime psychiatric and substance use disorders. American journal of psychiatry, 160 (3) (2003) 496-503. DOI: https://doi.or g/10.1176/appi.ajp.160.3.496

[19] N. S. Degeng, F. Hanurawan, T. Chusniah. The Effect Of Self-Regulated Learning On High School Students'self-Efficacy. International Journal Of Development Research, 7 (9183) (2017) 6-11. 